\title{
Consistency between Musrenbang Results and Southeast Aceh District Government Work Plan (RKP)
}

\author{
Hendra, Erlina, Asfriyati \\ University of Sumatra Utara, Indonesia
}

\begin{abstract}
This research presents the latest information on the analysis of Islamic law on the practice of fulfilling the rights of wives and children in the household among the Tablighi Jama'ah. This research is presented in a qualitative form with the approach of sociology of law (Islamic law). This study uses Islamic law (mashlahat theory) as an analysis tool in analyzing research data. In the end, this study concluded that the rights and obligations of husband and wife and children in the household among the Tablighi Jama'ah were actually subject to and did not differ from the provisions of Law No. 1 of 1974, KHI and so from the opinion of Imam Shafi'i, although in reality related to the Tablighi Jama'ah policy, especially when selecting members who want to leave the khuruj still needs to be improved so that there are no more members of the jama'ah who are mentally incapable, especially financially making khuruj, so this does not impact on the non-implementation of the obligations of the husband in the household and the poor image of preaching khuruj in the midst of society, especially the city of Medan.
\end{abstract}

\section{Keywords}

wife's right; jama'ah tabligh; khuruj; Medan

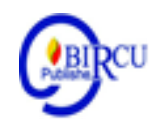

\section{Introduction}

Consistency between the proposed planning and the government work plan is important because it is an indicator in assessing the performance of local governments, so that all government programs and activities run well to achieve the goals set. This is very influential on the achievement of the vision, mission, goals, targets and policies that have been planned in the planning document and has an important role in the implementation of development to improve the welfare of the community through programs that aim to improve the quality of human resources and enhance economic growth.

The consistency between proposals and government work plans also affects the achievement of an organization's performance targets, in other words that the higher the proposal reflects the achievement of the plan the better the level of achievement. From the explanation above, the researcher feels interested to study the extent of the consistency of the government's proposals and work plans and their implications for achieving performance targets in the Southeast Aceh Regional Development Planning Board.

\section{Review of Literature}

\subsection{Planning System}

Since the issuance of Law Number 25 of 2004 concerning the National Development Planning System (SPPN) and Law Number 32 of 2004 concerning Regional Governments, the substance and essence of the development planning system becomes increasingly necessary to be improved in order to better guarantee the implementation of development in central and regional more effective and efficient. Based on this, in each autonomous region a body called a Regional Development Planning Agency (BAPPEDA) was formed as is the case in Southeast Aceh District. Regional Development Planning Agency (BAPPEDA) is 
urgently needed so that regional development planning can run well because there are institutions that are directly responsible, community participation as a manifestation of the seriousness of the community overseeing the course of development needs to be supported by the availability of public participation in providing input reflect people's aspirations.

Terry (in Soekarno, 1992: 71) argues that planning is: A description of what will be achieved, which then provides guidelines, outlines of what will be addressed. Planning is preparation rather than the implementation of a goal.

\subsection{Technocratic Approach (Strategic and Performance Based)}

The RKPK document is basically a process of strategic thinking. The quality of RKPK documents is largely determined by the quality of the programs and activities proposed by RKPK in achieving the regional development goals and targets agreed in the RKPK Musrenbang. The preparation of the RKPK is closely related to competencies in compiling, organizing, implementing, controlling, and evaluating the achievements of programs and activities.

\subsection{Democratic and Participatory Approaches.}

A democratic and participatory approach means that the RKPK contains the following matters:

1. Identification of relevant stakeholders to be involved in the decision making process at each stage of the preparation of the RKPK,

2. Equality between stakeholders from government and non-government elements in decision making,

3. Transparency and accountability in the planning process,

4. Adequate representation of all segments of society, especially women and marginalized groups,

5. A sense of community ownership of the RKPK,

6. Media engagement,

7. Implementation of quality RKPK Musrenbang in terms of implementing participatory planning,

8. Consensus or agreement at all important stages of decision making, such as: formulation of priority issues and problems, formulation of objectives, strategies, and policies and program priorities.

\subsection{Political Approach}

The political approach means that the RKPK contains the following matters:

1. Consultation with the Regional Head for a proper, systematic translation of the vision, mission, and program of the Regional Head into the objectives, strategies, policies and regional development programs,

2. The active involvement of the DPRD in the process of preparing the RKPK,

3. The community's aspiration net (recess) by the DPRD is an integral part of the RKPK preparation process,

4. Main ideas of the DPRD in the process of preparing the RKPK,

5. Discussion on the Draft Regional Head Regulation concerning RKPK which after stipulation will bind all parties as a reference in the preparation of the RAPBD

\subsection{Bottom-up approach}

The bottom-up approach means that the RKPK contains the following matters:

1. Networking people's aspirations and needs to see consistency with the vision, mission and programs of the Chosen Regional Head. 
2. Paying attention to the results of the musrenbang process and agreement with the community regarding regional development priorities.

3. Considering the results of the SKPD Forum

\subsection{Top-down approach}

The top-down approach means that the RKPK contains the following matters:

1. Synergy with RKP and RENJA K / L.

2. Synergy and consistency with the RPJMD and RPJPD.

3. Synergy and consistency with the RTRWD.

4. Handling problems with a holistic approach and a systems approach.

\section{Research Method}

The research location was conducted in the Southeast Aceh Regency Government Area. This research uses a qualitative approach with a case study method. Qualitative research is research that intends to understand phenomena about what is experienced by research subjects holistically and by means of descriptions in the form of words and languages, on a particular context that is natural and utilizes various natural methods according to Moleong (2012: 6)

Written documents, archives and others are sources of data at the Regional Development Planning Agency (BAPPEDA) of Southeast Aceh Regency or other institutions related to research are secondary data sources according to Moleong (2001: 157).

\section{Discussion}

\subsection{Consistent programs and activities}

Based on the results of the agreement in the implementation of musrenbang both at the village, sub-district and district levels there are consistent programs and activities, as shown in the following table:

Table 1. Proposed Musrenbang and Consistent Government Work Plan of Southeast Aceh District

\begin{tabular}{|c|c|c|c|c|c|}
\hline \multirow{3}{*}{ No } & \multicolumn{4}{|c|}{ Planning Documents } & \multirow{3}{*}{$\begin{array}{l}\text { Consistency } \\
\text { Assessment }\end{array}$} \\
\hline & \multicolumn{2}{|c|}{$\begin{array}{c}\text { District } \\
\text { Musrenbang (\%) }\end{array}$} & \multicolumn{2}{|c|}{$\begin{array}{c}\text { RKPK } 2019 \\
(\%) \\
\end{array}$} & \\
\hline & Prog & Keg & Prog & Keg & \\
\hline 1 & 2 & 3 & 4 & 5 & 6 \\
\hline $\begin{array}{l}\text { Bid Aceh features and human } \\
\text { resources }\end{array}$ & 100 & 96,41 & 100 & 91,76 & Consistent \\
\hline $\begin{array}{l}\text { Bid Development of Facilities } \\
\text { and Infrastructure }\end{array}$ & 100 & 94,12 & 100 & 91,08 & Consistent \\
\hline $\begin{array}{l}\text { Bid Pemb. Economics and } \\
\text { Employment }\end{array}$ & 100 & 93,87 & 100 & 94,22 & Consistent \\
\hline
\end{tabular}

The results of the percentage of consistency of the proposed Musrenbang and the work plan of the Southeast Aceh Regency Government in 2018-2019 there are 3 (three) areas studied: (1) Aceh and Human Resources Development Specialties Sector where the musrenbang documents in the activities reached $96.41 \%$, while in the RKPK document the activities having $91.76 \%$ is seen to be still consistent, (2) the construction of facilities and infrastructure at the consistency level activities that is $94.12 \%$, but in the RKPK document the level of consistency has increased to 91.08\%, and (3) the field of Economic Development 
and Energy The work where the percentage of musrenbang results reached $93.87 \%$, but in the Southeast Aceh Regency government work plan documents only reached $94.22 \%$.

\subsection{Inconsistent programs and activities}

In the implementation of the musrenbang it is often found or encountered activities that are not stamped or agreed upon, activities that are not agreed upon in the previous planning document, but appear at the level of the implementation of the next planning document called inconsistent activities. As in the table below:

Table 2. Inconsistent Musrenbang and Work Plan of Southeast Aceh District Government

\begin{tabular}{|c|c|c|c|c|c|}
\hline \multirow{3}{*}{ No } & \multicolumn{4}{|c|}{ Planning Documents } & \multirow{3}{*}{$\begin{array}{l}\text { Consistency } \\
\text { Assessment }\end{array}$} \\
\hline & \multicolumn{2}{|c|}{$\begin{array}{c}\text { District } \\
\text { Musrenbang (\%) }\end{array}$} & \multicolumn{2}{|c|}{$\begin{array}{c}\text { RKPK } 2019 \\
(\%)\end{array}$} & \\
\hline & Prog & Keg & Prog & Keg & \\
\hline 1 & 2 & 3 & 4 & 5 & 6 \\
\hline $\begin{array}{l}\text { Bid Aceh features and } \\
\text { human resources }\end{array}$ & 0 & 3,58 & 0 & 8,23 & Inconsistent \\
\hline $\begin{array}{c}\text { Bid Development of } \\
\text { Facilities and Infrastructure }\end{array}$ & 0 & 5,87 & 0 & 8,91 & Inconsistent \\
\hline $\begin{array}{l}\text { Bid Pemb. Economics and } \\
\text { Employment }\end{array}$ & 0 & 6,12 & 0 & 5,77 & Inconsistent \\
\hline
\end{tabular}

In table 2 it is explained where in the area of Privileges and HR there are inconsistencies in defining programs and activities which will later become a permanent reference in the district government budgeting process for the next 1 year, namely in the Musrenbang documents there are $3.58 \%$ inconsistent activities, whereas in there are $8.23 \%$ RKPK documents which are inconsistent. In the field of facilities and infrastructure the inconsistencies in activities reached $5.87 \%$, while in the RKPK the level of inconsistency was $8.91 \%$, and in the economic and employment sector the inconsistencies of activities reached $6.12 \%$ while in the RKPK document there were $5.77 \%$.

Both of these categories, researchers can formulate based on the percentage of consistency of the proposed sectoral document in which the level of consistency in the implementation of the district musrenbang with the Southeast Aceh district government work plan document can be seen in the following table:

Table 3. Comparison of the Musrenbang Document Inconsistencies with the Southeast Aceh District Government Work Plan in 2019

\begin{tabular}{|c|c|c|c|c|c|}
\hline \multirow{3}{*}{ No } & \multirow{3}{*}{ Field of Affairs } & \multicolumn{4}{|c|}{ Planning Documents } \\
\hline & & \multicolumn{2}{|c|}{$\begin{array}{c}\text { District Musrenbang } \\
(\%)\end{array}$} & \multicolumn{2}{|c|}{$\begin{array}{c}\text { RKPK } 2019 \\
(\%) \\
\end{array}$} \\
\hline & & Program & Activity & Program & Activity \\
\hline 1 & 2 & 3 & 4 & 5 & 6 \\
\hline 1 & $\begin{array}{l}\text { Aceh features and } \\
\text { human resources }\end{array}$ & 0 & 3,58 & 0 & 8,23 \\
\hline 2 & $\begin{array}{l}\text { Facilities and } \\
\text { infrastructure }\end{array}$ & 0 & 5,87 & 0 & 8,91 \\
\hline 3 & $\begin{array}{l}\text { Economics and } \\
\text { Employment }\end{array}$ & 0 & 6,12 & 0 & 5,77 \\
\hline & Total & $\mathbf{0}$ & 15,57 & $\mathbf{0}$ & 22,91 \\
\hline
\end{tabular}


In the table it is explained that the Southeast Aceh district musrenbang planning document in which the programs in the musrenbang are consistent with the subdistrict musrenbang documents, while the activity reaches an inconsistency level of $15.57 \%$. Whereas in the Southeast Aceh district government work plan document where the programs are synchronized from the district musrenbang program, while the activities agreed upon in the RKPK document are not consistent at $22.91 \%$.

\subsection{Musrenbang Documents and Aceh Tenara District Government Work Plan}

The Musrenbang proposal and the Southeast Aceh District Government Work Plan can be analyzed through the main contents of each Musrenbang and RKPK documents. Local government policy as stipulated in the medium-term development plan (RPJMK) is a policy that guides the district apparatus unit (SKPK) in preparing a strategic plan in accordance with its main tasks and functions. Therefore, the elaboration of policies into local government programs must be formulated by taking into account the level of consistency of their elaboration if necessary to arrive at indicative activity formulations. The importance of consistent translation from the formulation of the policy to the formulation of indicative activities will provide convenience and clarity to each SKPK as the technical implementer of the policy. Each SKPK must be able to draw the red thread of each policy contained in the RPJMK.

The successful implementation of regional autonomy in an effective and efficient manner must be supported by the extent to which the region maintains good consistency of every policy translation into various relevant programs. During the implementation of regional autonomy and fiscal decentralization, especially after the issuance of Law No. 25 of 2004 concerning SPPN followed by government regulations such as PP 08 of 2008 concerning the stages of preparation and evaluation of regional development planning, each region is required to compile planning documents consistently both in terms of the structure as regulated in the Law and the substance of the translation.

\section{a. District Musrenbang}

Sub-district Musrenbang in Southeast Aceh District is carried out by all 16 subdistricts, sub-district musrenbang is attended by delegates from each SKPK to discuss and agree on proposed development activities that are priority development activities in the concerned sub-districts and discuss and agree on priority development activities in subdistrict areas that have not been included in the priority of village development activities and agreed on the grouping of development priority activities in the sub-district area based on the tasks and functions of the Southeast Aceh SKPK.

Priority document Proposed development activities resulting from the implementation of the District Level Development Planning Consultation Meeting (Musrenbang) will continue as discussion material at the District Level Musrenbang. The results of the District Level Musrenbang will be informed to the public through the District delegation, so that the community knows what activities have been accommodated to be carried out the following year, and if there are activities that are not accommodated, they will be planned / studied to be used as material for discussion in the planning development in the following year.

Table 4: Agreement Results for Sub-District Musrenbang Programs / Activities

\begin{tabular}{|c|l|c|c|}
\hline \multirow{2}{*}{ No } & \multirow{2}{*}{ Proposed Field } & \multicolumn{2}{|c|}{2018} \\
\cline { 3 - 4 } & & Program & Activity \\
\hline 1 & Aceh Special Development and HR & 66 & 215 \\
\hline 2 & Construction of facilities and infrastructure & 43 & 481 \\
\hline 3 & Economic Development and Employment & 31 & 383 \\
\hline \multicolumn{2}{|c}{ Total } & 140 & 1.079 \\
\hline
\end{tabular}


Source: Southeast Aceh Regency Bappeda in 2018 - 2019

Table 4 sourced from the Southeast Aceh District Bappeda in 2018-2019 can be explained that the results of the agreement of the proposed sub-district programs / activities are based on the SKPK field where (1) the Aceh Specialist and Human Resources Sector recorded 66 program proposals and consisted of 215 activities carried out in the year musrenbang 2018 ago (2) the Facilities and Infrastructure Development Sector had 43 programs and 481 activities and (3) the Economic Development and Employment Sector had 31 programs and 383 activities.

\section{b. District Musrenbang}

The draft RKPK will later become material for the next process, namely the district musrenbang in the implementation of group meetings to synchronize, oversee and incorporate program activities, board thoughts, SKPK work plan according to priorities and development themes with the final result being the Final RKPK Draft and after consultation with the Regent and later revised was ratified as RKPK as a regional planning document. The planning documents for the results of the district musrenbang can be seen in the following table:

Table 5: Agreement Results of District Musrenbang Programs / Activities

\begin{tabular}{|c|l|c|c|}
\hline \multirow{2}{*}{ No } & Proposed Field & \multicolumn{2}{|c|}{2018} \\
\cline { 3 - 4 } & & Program & Activity \\
\hline 1 & Aceh Special Development and HR & 66 & 223 \\
\hline 2 & Construction of facilities and infrastructure & 43 & 511 \\
\hline 3 & Economic Development and Employment & 31 & 408 \\
\hline \multicolumn{2}{|c|}{ Total } & 140 & 1.142 \\
\hline
\end{tabular}

Source: Southeast Aceh Regency Bappeda in 2018 - 2019

Table 5 explains that the Aceh Special Development and HR Sector has 66 programs and 223 activities as well as the Infrastructure and Development Sector there are 43 programs and 511 activities where the Economic Development and Employment Sector has only 31 programs and 408 activities, so that in a joint agreement the results of the district musrenbang there are 140 programs and 1,142 activities spread across the District Work Unit (SKPK) based on the Proposed Field from the subdistrict musrenbang.

\subsection{Analysis of the consistency of musrenbang documents based on the proposed field}

Analysis of consistency between the district musrenbang documents and the 2019 Regency Government Work Plan can be seen in the following consistency table:

Table 6. Aceh Special Region Development and Human Resources

\begin{tabular}{|c|c|c|c|c|c|c|}
\hline \multirow{2}{*}{ No } & \multicolumn{2}{|c|}{ Program Status } & \multicolumn{2}{|c|}{ District Musrenbang } & \multicolumn{2}{|c|}{$\begin{array}{c}\text { RKPK } \\
\text { 2019 }\end{array}$} \\
\cline { 4 - 7 } & \multirow{2}{*}{1} & Program & Activity & Program & Activity \\
\hline \multirow{2}{*}{1} & 2 & 4 & 5 & 6 & 7 \\
\hline \multirow{2}{*}{1} & \multirow{2}{*}{ Consistent } & Total & 66 & 223 & 66 & 243 \\
\cline { 3 - 7 } & & $(\%)$ & 100 & 96,41 & 100 & 91,76 \\
\hline \multirow{2}{*}{2} & \multirow{2}{*}{ Inconsistent } & Total & 0 & 8 & 0 & 20 \\
\cline { 3 - 7 } & & $(\%)$ & 0 & 3,58 & 0 & 8,23 \\
\hline
\end{tabular}

The results of the agreement on the District Musrenbang Documents in the area of privilege and human resource development have 66 programs and have 223 activities, while in the District Government Work Plan there are 66 programs with a consistent percentage 
reaching $100 \%$, while in activities there is an increase reaching $8.23 \%$ due to additional activities.

Table 7. Sector Development of facilities and infrastructure

\begin{tabular}{|c|c|c|c|c|c|c|}
\hline \multirow{2}{*}{ No } & \multirow{2}{*}{ Program Status } & \multicolumn{2}{|c|}{ District Musrenbang } & \multicolumn{2}{|c|}{ RKPK } \\
\cline { 3 - 7 } & \multirow{2}{*}{$\mathbf{2 0 1 9}$} \\
\cline { 3 - 7 } & $\mathbf{2}$ & $\mathbf{3}$ & $\mathbf{4}$ & $\mathbf{5}$ & $\mathbf{6}$ & $\mathbf{7}$ \\
\hline \multirow{2}{*}{1} & \multirow{2}{*}{ Consistent } & Total & 43 & 511 & 43 & 561 \\
\cline { 3 - 7 } & $(\%)$ & 100 & 94,12 & 100 & 91,08 \\
\hline \multirow{2}{*}{2} & \multirow{2}{*}{ Inconsistent } & Total & 0 & 30 & 0 & 50 \\
\cline { 3 - 7 } & & $(\%)$ & 0 & 5,87 & 0 & 8,91 \\
\hline
\end{tabular}

Table 7 shows that the functions in the field of infrastructure and development after comparing the district musrenbang documents with the RKPK document in 2019 there was no reduction in the program. While in the results of the 2019 RKPK document agreement there was an increase in activities reaching $8.91 \%$ from the district musrenbang, this was caused by the emergence of policies towards local stakeholders (DPRK members, SKPK and demands from other parties).

Table 8. Economic Development and Employment Sector

\begin{tabular}{|c|c|c|c|c|c|c|}
\hline \multirow{2}{*}{ No } & \multicolumn{2}{|c|}{ Program Status } & \multicolumn{2}{|c|}{ District Musrenbang } & \multicolumn{2}{|c|}{$\begin{array}{c}\text { RKPK } \\
\text { 2019 }\end{array}$} \\
\cline { 3 - 7 } & & Program & Activity & Program & Activity \\
\hline $\mathbf{1}$ & $\mathbf{2}$ & $\mathbf{3}$ & $\mathbf{4}$ & $\mathbf{5}$ & $\mathbf{6}$ & $\mathbf{7}$ \\
\hline \multirow{2}{*}{1} & \multirow{2}{*}{ Consistent } & Total & 31 & 408 & 36 & 433 \\
\cline { 3 - 7 } & $(\%)$ & 100 & 93,87 & 100 & 94,22 \\
\hline \multirow{2}{*}{2} & \multirow{2}{*}{$\begin{array}{c}\text { Inconsiste } \\
\text { nt }\end{array}$} & Total & 0 & 25 & 0 & 25 \\
\cline { 3 - 7 } & $(\%)$ & 0 & 6,12 & 0 & 5,77 \\
\hline
\end{tabular}

The table above can be seen that the district musrenbang documents have not changed. At the time of the establishment of the 2019 District Government Work Plan document, the activity actually experienced an increase of $5.77 \%$ from the district musrenbang document. the planning.

The results of the musrenbang agreement are a document in government planning carried out during one fiscal year. In the following table the researcher displays the activities that have changed in the form of additional activities so as to cause the inconsistency of a planning document in each of the proposed fields that are revealed in each SKPK.

\section{Conclusion}

The results of the research on the Consistency of Proposed Activities from the Musrenbang in the 2019 Government Work Plan in Southeast Aceh District are the Consistency of the proposed Musrenbang and the Southeast Aceh District Government work plan in 2018-2019 there are 3 (three) areas studied: (1) the Aceh Special Development Sector and HR in the Musrenbang document has a level of consistency in activities of only $96.41 \%$ and the inconsistency reached $3.58 \%$ while in the Southeast Aceh Regency government work plan is $90.53 \%$, and the inconsistency is $8.23 \%$, (2) the construction of facilities and Infrastructure in the Musrenbang document is a consistent level of $94.12 \%$ while the inconsistency is $5.87 \%$, while in the district government work plan documents the consistency level is $91.08 \%$ and there is an inconsistency seen from the percentage reaching 8.91\%, and (3) Economic Development and Employment where in the results of the Musrenbang the percentage level consistently reached $93.87 \%$ and keti inconsistency $6.12 \%$, 
but in the Southeast Aceh Regency government work plan document the level of consistency only reached $94.22 \%$ and the inconsistency reached $5.77 \%$ so the inconsistency between the Musrenbang documents and the Southeast Aceh district government work plan document reached $22.91 \%$.

The frequent inconsistencies between planning documents that are reflected in annual plans are generally caused by several factors including:
a) The quality of the planner is weak,
b) HR planners often experience mutations,
c) There is no commitment in the organization to maintain consistency of programs and activities,
d) Legislative intervention is very high,
e) Intervention of Regional Heads

\section{References}

Abe, Alexander. 1994. Perencanaan Daerah Partisipatif. Pustaka Jogja Mandiri. Yogyakarta.

Adisasmita, Raharjo. Pengembangan wilayah. Graha Ilmu. Jakarta

Alkadri.et.al. 2001. Manajemen Teknologi Untuk Pengembangan Wilayah. Edisi Revisi Pusat Pengembangan Kebijakan Teknologi Pengembangan Wilayah-BPPT Press. Jakarta.

Arbit, Sanit. 1985. Perwakilan Politik Indonesia. Rajawali. Jakarta.

Arikunto, Suharsimi. 1996. Prosedur Penelitian suatu pendekatan Praktek, Rineka Cipta. Jakarta.

Conyer dan Diana. 1991. Perencanaan Sosial di Dunia Ketiga. Gajah Mada Press. Yograkarta.

Direktorat Pengembangan Wilayah dan Transmigrasi.2003. Pendekatan Pengembngan Wilayah. Departemen Ilmu administrasi Fisip-UI. Jakarta

Edi, Suharto. 2006. Membangun Masyarakat Memberdayakan Rakyat, Kajian strategis pembangunan kesejahteraan social dan pekerjaan sosial, Aditama. Bandung.

Harun, Hamrolie. 2005. Analisa Kelayakan Proyek Pembangunan Daerah. Edisi Umum. Jakarta.

Irawan, Prestya. 2006. Penelitian Kualitatif dan Kuantitatif untuk Ilmu Sosial. Komputindo. Jakarta

Karyono, O.(2019). Determining the Priority Strategy in the Implementation of EGovernment Through Swot Analysis Model. Budapest International Research and Critics Institute (BIRCI-Journal), p. 66-74.

Moeljarto. T. 1993. Politik pembangunan sebuah Analisa Konsep, Arah dan Strategi. Jakarta Mulyanto, H.R. Prinsip-prinsip Pengembangan Wilayah. Graha Ilmu. Jakarta

Nugroho, Rian. Reinventing Pembangunan. Elex Media Komputindo. Jakarta

Nyoman Sumaryadi. 2005. Perencanaan Pembangunan daerah, Gramedia Pustaka. Jakarta

Wrihatnolo, R. Randy. 2006. Manajemen Pembangunan Indonesia, PT Elex Media. Jakarta

Rasyid, M. Ryasss. 1998. Kajian Arah Birokrasi Pemerintah dan Politik Orde Baru. Yarsif Watampone. Jakarta.

Riyadi, deddy Supriady. 2005. Perencanaan Pembangunan Daerah. Gramedia Pustaka. Jakarta.

Soehardjo, Rudy. 2004. Mengenal Pelaksanaan Tugas DPRD Kabupaten/Kota. Aneka Ilmu.Semarang.

Suparlan, Parsudi. Pembangunan yang Terpadu berkesinambungan. Tiara Wacana. Yogyakarta. 